\title{
Key Plant, Key Pests: Holly (Ilex sp.) ${ }^{1}$
}

Juanita Popenoe, Caroline R. Warwick, Jacqueline Bourdon, and Liz Felter ${ }^{2}$

\section{Key Plant: Holly (Ilex sp.)}

Hollies (Ilex sp.) are a diverse group found naturally and horticulturally grown throughout Florida. This woody species has a wide range of forms which are typically evergreen. While growing best in partial shade, many will thrive in full sunlight. Well-drained, slightly acidic soils provide the best growing conditions for most species, Dahoon holly (Ilex cassine) being the exception. Dahoon holly tends to grow more on hydric (wet) sites. Hollies are common throughout the southeast, natively growing in USDA hardiness zones 8-11. Male and female flowers are on separate plants. The red berries, the commonly recognized feature of hollies, are found only on female plants. Female plants are asexually propagated and cultivated for ornamental use to ensure berries. Hollies provide a great aesthetic quality to landscapes with little maintenance (Brown 2018).

\section{Key Pests: Holly}

This series of Key Plant, Key Pests publications are designed for Florida gardeners, horticulturalists, and landscape professionals to help identify common pests associated with common Florida flora. This publication, the eighth in the Key Plant, Key Pests series, helps identify the most common pests found on holly (Ilex sp.).

This publication provides information and general management recommendations for Florida wax scale, tea scale, Cylindrocladium leaf spot, dieback, Sphaeropsis gall, root knot nematodes, and magnesium deficiency. For a more comprehensive guide of woody ornamental insect management, download the current Professional Disease Management Guide for Ornamental Plants or the Integrated Pest Management in the Commercial Ornamental Nursery Guide. Additionally, the 2017 Southeast Pest Management Guide may provide specific chemical recommendations for controlling pests.

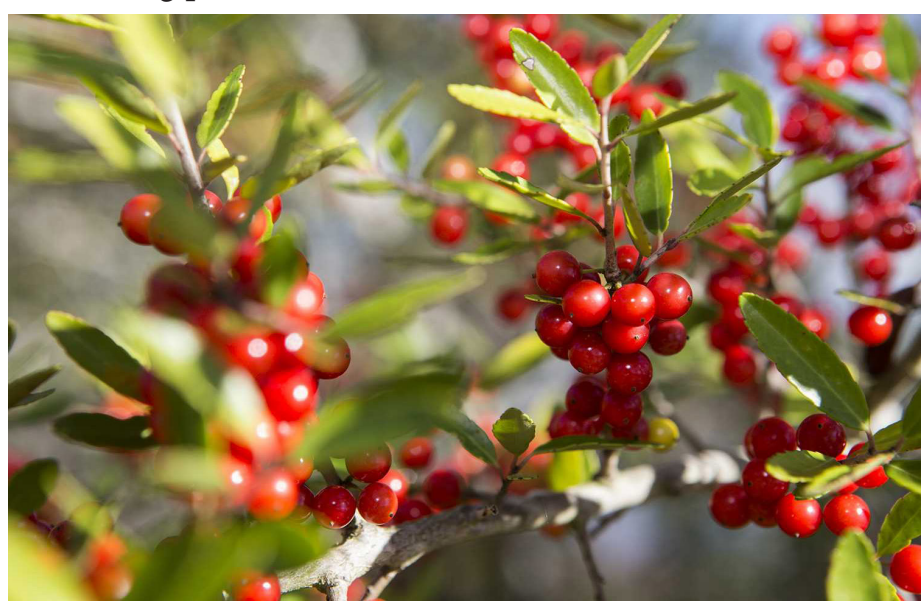

Figure 1. Hollies are known for their woody branches and vibrant red berries.

Credits: Tyler Jones, UF/IFAS

\section{Florida Wax Scale (Ceroplastes floridensis Comstock) RECOGNITION}

The mature scale is round and convex, creamy in color, and is found on stems or tops of leaves. It is a soft scale which exudes "honey dew" and supports the growth of sooty mold on the leaves beneath. Pinkish crawlers are followed by

1. This document is ENH1302, one of a series of the Environmental Horticulture Department, UF/IFAS Extension. Original publication date October 2018. Visit the EDIS website at https://edis.ifas.ufl.edu for the currently supported version of this publication.

2. Juanita Popenoe, multi-county commercial fruit production agent IV; Caroline R. Warwick, science communications specialist; Jacqueline Bourdon, communications intern; and Liz Felter, Extension agent II; UF/IFAS Mid-Florida Research and Education Center, Apopka, FL 32703. 
early instars that look like white fringed stars. Adults are dark reddish brown beneath a thick pinkish-white waxy covering. Feeding damage results in chlorotic spots on the leaves, possible leaf drop, and branch dieback. The presence of sooty mold may also indicate wax scales (Sharma and Buss 2011). For more information on Florida wax scale, refer to EENY-510, Florida Wax Scale, Ceroplastes floridensis Comstock.

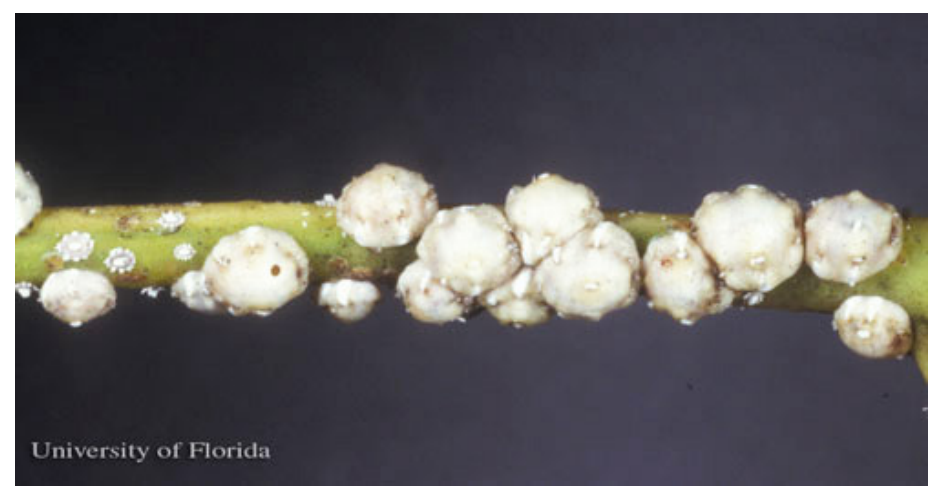

Figure 2. Adult Florida wax scales; a few nymphs are visible on the left. Credits: Lyle J. Buss, UF/IFAS

\section{CONTRIBUTING FACTORS}

As with most scales, it may be present year-round. Crawlers hatch in spring and should be monitored throughout the warm season. There tend to be three generations per year in Florida due to warm summers. The scale can infest a variety of other ornamental plants and crops, including citrus, oaks, crapemyrtle, avocado, and Indian hawthorn, making control a problem.

\section{MANAGEMENT RECOMMENDATIONS}

Biological, cultural, and chemical controls are used to control this disease. If scale populations build to objectionable levels, oils or other approved insecticides may be used. The crawlers are the easiest stage to control.

\section{Tea Scale (Fiorinia theae Green) RECOGNITION}

Tops of infested leaves show yellow markings typical of piercing-sucking insect feeding. Undersides of leaves may appear fuzzy and whitish from the large numbers of scales. Distorted young leaves may be early signs of infestation. Tea scale is a very small, armored scale. The female scale is one-twentieth of an inch long and brown in color; the male is even smaller and white (Miller 2016). Armored scales do not produce "honey dew," so sooty mold will not be seen with these types of scales. For more information on tea scale, refer to EENY250, Tea Scale, Fiorinia theae Green (Insecta: Hemiptera: Diaspididae).

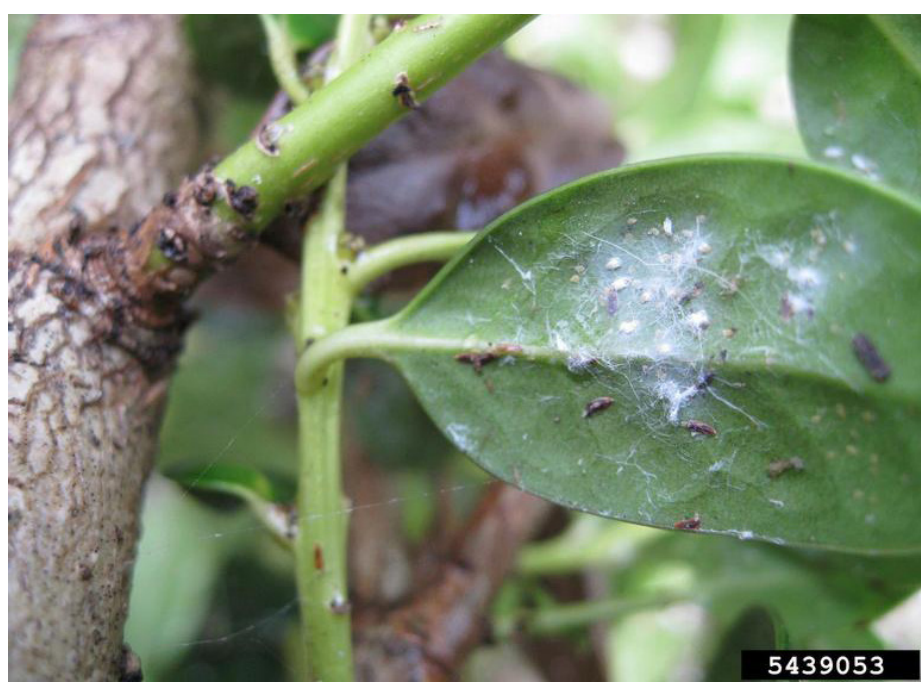

Figure 3. Ilex sp. showing symptoms of tea scale infestation. Credits: Chazz Hesselein, Alabama Cooperative Extension Systems, Bugwood.org

\section{CONTRIBUTING FACTORS}

In Florida, Fiorinia theae Green remains active throughout the year due to warm winters. In cooler climates hatching will often coincide with the warming spring temperatures.

\section{MANAGEMENT RECOMMENDATIONS}

If scale populations build to objectionable levels, approved soaps, oils, or insecticides may be used. The crawlers are the easiest stage to manage. Applying sprays in the spring is the best time of year, as the danger of cold weather has passed and egg hatching coincides with warm temperatures. There are biological controls available, as several US-native wasps (including Aphytis diaspidis) will parasitize tea scales.

\section{Cylindrocladium leaf spot (Cylindrocladium spp.) RECOGNITION}

Although several fungi occasionally cause spotting on various hollies, Cylindrocladium can cause a serious disease. Symptoms are severe leaf spotting, defoliation, twig dieback, and sometimes death of new plantings. Leaf spots initially are minute chlorotic spots which enlarge and become circular and dark purple to black. Affected leaves drop easily; twigs may become infected and result in dieback (Hagan 2005).

\section{CONTRIBUTING FACTORS}

This disease occurs most commonly on Ilex vomitoria, but can also attack I. cornuta, I. crenata and I. opaca. Favorable environmental conditions are warm temperatures, high humidity, and excessive leaf wetness. Spores form on affected leaves on the plant or on fallen leaves and are spread by splashing water. 


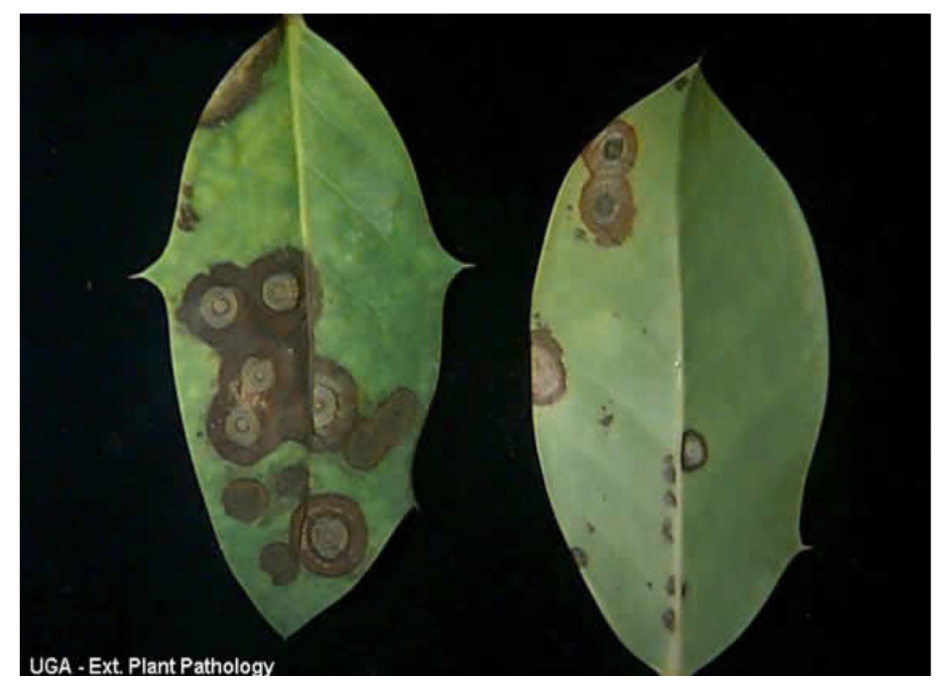

Figure 4. Cylindrocladium leaf spot symptoms on holly leaves. Credits: University of Georgia Department of Plant Pathology Plant Disease Library

\section{MANAGEMENT RECOMMENDATIONS}

Adjust irrigation to keep the foliage as dry as possible. If disease occurs, rogue infected plants, remove fallen leaves and apply fungicides at regular intervals.

\section{Dieback (Various Fungi) RECOGNITION}

Dieback refers to symptoms caused by a variety of fungi. Typically seen on Dwarf Yaupon holly, branch diebacks cause the leaves to wilt and turn brown, eventually leaving holes in the canopy or bare areas that ruin the symmetrical shape of the plant. Observation of a pink- or white-colored fungus mat on the dead or dying branches is indicative of one disease, called pink limb blight. Other fungi may not show external symptoms. The spores are rain-splashed and/ or windblown to other branches and plants, where they enter the plant through wounds (Brown 2018).

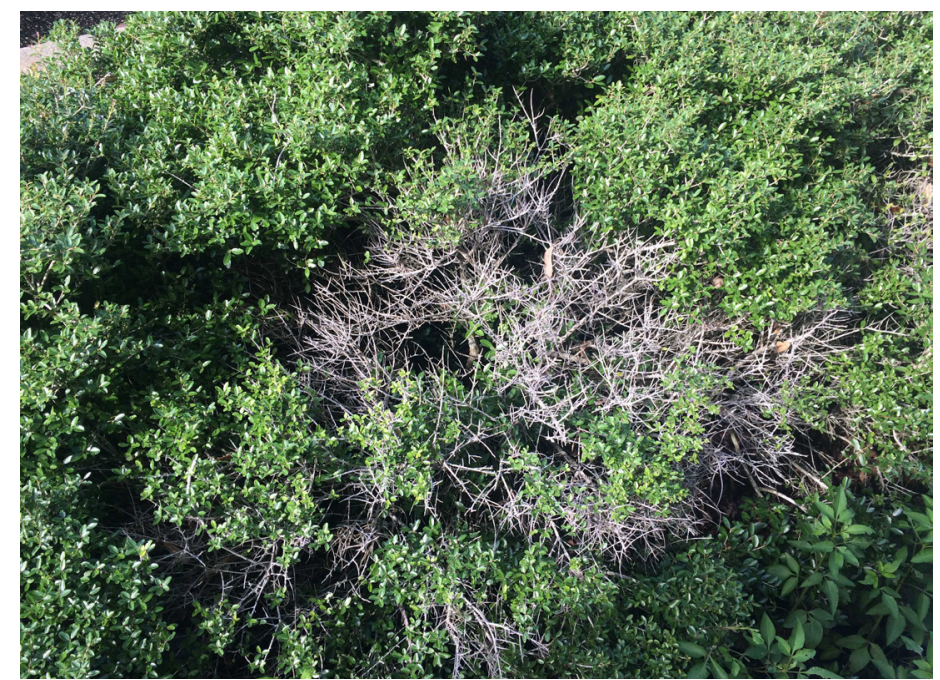

Figure 5. Hollies exhibiting signs of dieback.

Credits: Juanita Popenoe, UF/IFAS

\section{CONTRIBUTING FACTORS}

The disease occurs most often in dense plantings and/or on plants which are frequently moist and excessively sheared. Any factors causing bark injury such as freezes, drought, or pruning predispose the branch to possible infection. Rain or irrigation droplets easily spread the spores from infected branches.

\section{MANAGEMENT RECOMMENDATIONS}

Prune dead branches out well below the affected area. Fungicide applications immediately after pruning may help limit new infections. Replace cosmetically unacceptable plants. However, the fungus will remain in the soil and/ or mulch to start new infections; replacement with other species may be necessary in some areas.

\section{Sphaeropsis Tip Blight (Sphaeropsis tumefaciens) RECOGNITION}

Symptoms range from inconspicuous swellings of young twigs to irregular galls on older wood. Multiple shoots arise from galled areas, causing a "witches broom" type of growth. Horizontal branches can "tip up" to grow nearly vertically. Dieback of infected branches eventually occurs (Miller, McRitchie, \& Seymour 1977).

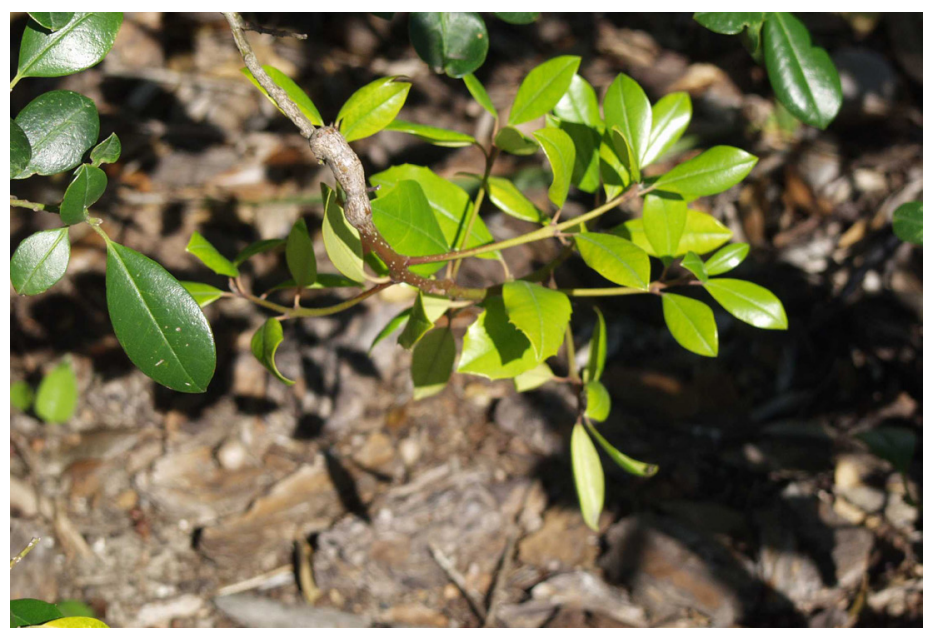

Figure 6. Evidence of Sphaeropsis or "witches broom" on 'East Palatka' holly.

Credits: Dave Norman, UF/IFAS

\section{CONTRIBUTING FACTORS}

Although many Ilex species are susceptible, Sphaeropsis tip blight has become a severe problem on 'East Palatka' and 'Savannah' hollies in particular. Natural or mechanical wounds in the wood allow entry points for the organism. Pruning may allow it to spread rapidly by transferring the fungus and allowing an entry point into the plant. Some pathologists believe it may even be transferred by bees. 


\section{MANAGEMENT RECOMMENDATIONS}

Prune branches 4 to 6 inches below symptoms. Prune during dry times, avoiding periods when rainfall is expected 24 hours before or after pruning. Sterilize pruners between cuts and/or plants. Fungicides are not effective except as a preventative sprayed immediately after pruning. Severely infected plants should be removed and destroyed.

\section{Nematodes}

\section{RECOGNITION}

Poor growth, plant decline, and thinning of the canopy may be symptoms of nematode infestation. Yellowing of foliage can occur. Infested roots have obvious galls and may be brown and stunted (Mathews 2012).

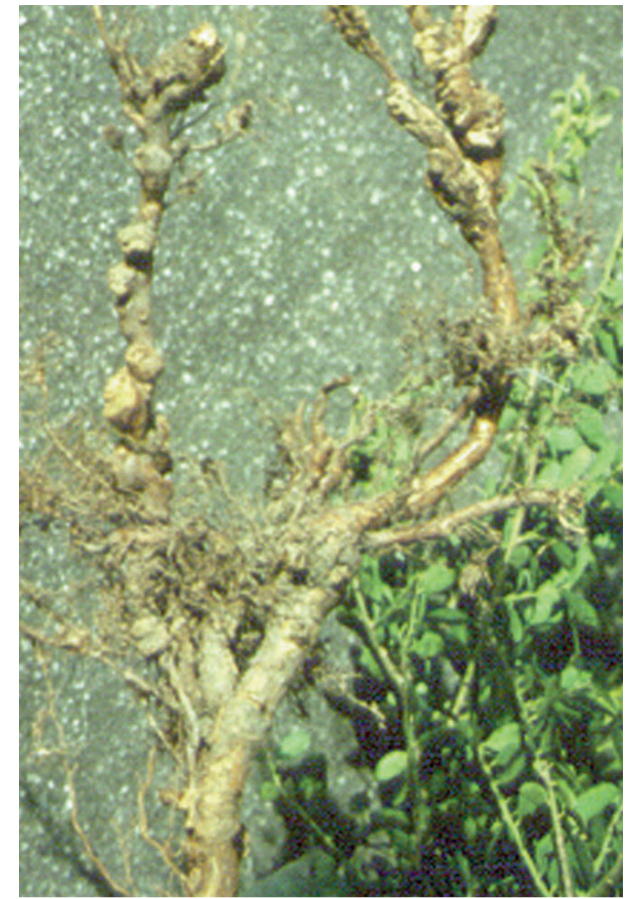

Figure 7. Galls produced by root-rot nematodes problems on a Japanese holly.

Credits: R. Jones, North Carolina State University, Alabama Cooperative Extension System

\section{CONTRIBUTING FACTORS}

Japanese holly is highly susceptible to nematodes. Susceptibility of other species is variable; for example, Ilex cornuta 'Rotunda' is considered susceptible, while Ilex cornuta 'Burfordii' is considered tolerant.

\section{MANAGEMENT RECOMMENDATIONS}

Keep plants as healthy as possible with adequate water and fertilizer to support new roots. No chemical controls are available for use on existing plants. When replacing plants, remove all roots and replace soil. Avoid replanting with susceptible species. For more information on nematode infestations in hollies, refer to Common Diseases of Holly and Their Control.

\section{Magnesium Deficiency RECOGNITION}

Yellowing along the margins of older leaves, often making a distinct yellow "V" shape on each leaf, is a symptom of magnesium deficiency. These symptoms appear on older growth and a reduction in new leaf size will occur.

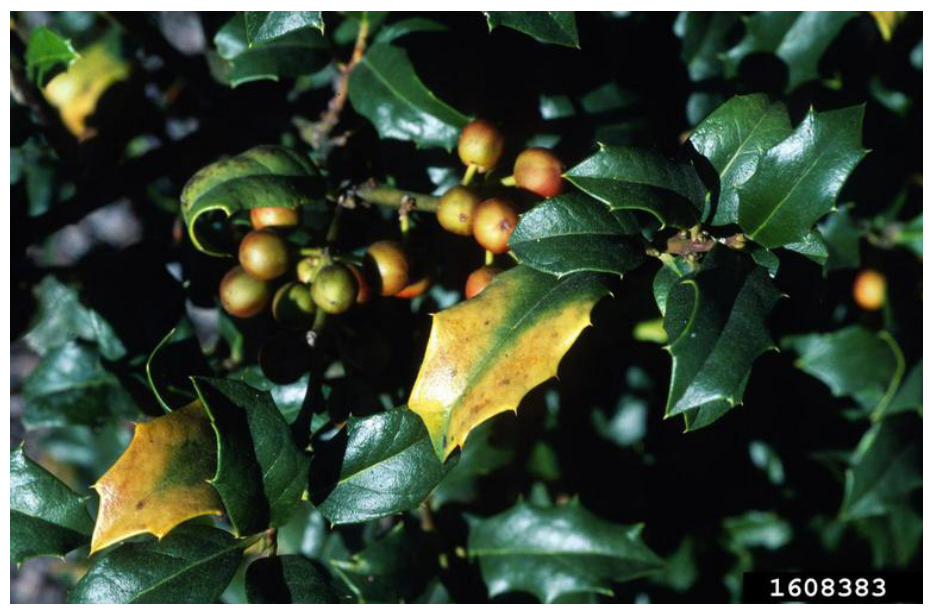

Figure 8. Magnesium deficiency on Holly leaves.

Credits: John Ruter, University of Georgia, Bugwood.org

\section{CONTRIBUTING FACTORS}

Holly seems more sensitive to magnesium deficiency than some other species. Low soil $\mathrm{pH}$ and/or lack of magnesium in the soil results in deficiency symptoms.

\section{MANAGEMENT RECOMMENDATION}

Check and adjust the soil $\mathrm{pH}$ with dolomite. Apply magnesium sulfate (Epsom salts) or fertilizers with magnesium.

\section{References}

Brown, S. B. 1990. Hollies at a glance. ENH42. Gainesville: University of Florida Institute of Food and Agricultural Sciences. http://edis.ifas.ufl.edu/mg021

Hagan, A. 2005. "Common diseases of holly and their control.” http://www.aces.edu/pubs/docs/A/ANR-1087/ ANR-1087.pdf

Mathews, T. 2012. "What can I do about nematodes?". http://go.ncsu.edu/readext? 180310

Miller, C. F. 2004. Tea scale, Fiorinia theae Green (Insecta: Hemiptera: Disapididae). EENY250. Gainesville: University of Florida Institute of Food and Agricultural Sciences. http://edis.ifas.ufl.edu/in522 
Miller, H. N., McRitchie, J. J., \& Seymour, C. P. 1977.

"Sphaeropsis witches' broom of holly." https://www.fresh-

fromflorida.com/content/download/11183/143389/pp176.

pdf

Sharma, S., \& Buss, E. 2011. "Florida wax scale, Ceroplastes floridensis Comstock (Insecta: Hemiptera: Coccoidea:

Coccidae)." http://entnemdept.ufl.edu/creatures/orn/scales/ florida_wax_scale.htm 